\title{
Management of soil phosphorus and plant adaptation mechanisms to phosphorus stress for sustainable crop production: a review
}

\author{
T. Balemi ${ }^{1 *}$ and K. Negisho ${ }^{2}$ \\ ${ }^{1}$ College of Agriculture \& Veterinary Science, Department of Plant Sciences \& Horticulture, Ambo University, \\ P.O. Box, 19, Ethiopia. ${ }^{2}$ Holeta Agricultural Research Center, National Agricultural Biotechnology Research \\ Program, P.O.Box 2003, Holeta, Ethiopia. 'Correspondingauthor: tesfayeb2005@yahoo.co.uk.
}

\begin{abstract}
Phosphorus is one of the seventeen essential nutrients required for plant growth. Despite its importance, it is limiting crop yield on more than $40 \%$ of the world's arable land. Moreover, global $\mathrm{P}$ reserves are being depleted at a higher rate and according to some estimates there will be no soil P reserve by the year 2050.This is a potential threat to sustainable crop production. Most of the $\mathrm{P}$ applied in the form of fertilizers may be adsorbed by the soil, and is not available for plants lacking specific adaptations. Available soil P and hence crop yield can, however, be increased through applying P containing fertilizers to feed the ever increasing world population. The $\mathrm{P}$ contained in crop residues if left in the field can be recycled by incorporating the residues into the soil whereas part of $\mathrm{P}$ in crop residues fed to livestock can be returned back to the soil in the form of manure and as bone meal. Additionally, plants have evolved a diverse array of strategies to obtain adequate $P$ for their growth under $\mathrm{P}$ limiting conditions (a term called as P-efficiency mechanisms). Plant P-efficiency mechanisms include both improved uptake efficiency (the ability of a plant to take up more $\mathrm{P}$ under $\mathrm{P}$ limiting condition) and improved utilization efficiency (the ability of a plant to produce higher dry matter yield per unit P taken up). Uptake efficiency mechanisms include modification of root architecture, development of large root system, longer root hairs and thinner roots, exudation of low molecular weight organic acids, protons and enzymes such as phosphatases and phytases, association with mycorrhiza, production of cluster roots and expression of high affinity P transporters all of which contribute to increased P uptake efficiency of the plant. Other mechanisms include the use of alternative P-independent enzymes and glycolytic pathways, efficient cytoplasmic $\mathrm{P}$ homeostasis and higher ability to remobilize $\mathrm{P}$ from other plant parts all of which are part of enhanced $\mathrm{P}$ utilization efficiency. Traits related to the above morphological, physiological, biochemical and molecular adaptation mechanisms under $P$ stress can be utilized in improving cultivated crops for P efficiency through breeding programs.
\end{abstract}

Keywords: adaptation mechanism, nutrient stress, phosphorus efficiency, soil phosphorus management. 


\section{Introduction}

Phosphorus is one of the seventeen essential nutrients required for plant growth (Ragothama, 1999). It is the second most important macronutrient next to nitrogen in limiting crop growth. Plant dry weight may contain up to $0.5 \%$ phosphorus and this nutrient is involved in an array of process in plants such as in photosynthesis, respiration, in energy generation, in nucleic acid biosynthesis and as an integral component of several plant structures such as phospholipids (Vance et al., 2003). Despite its importance in plants growth and metabolism, phosphorus is the least accessible macronutrient and hence most frequently deficient nutrient in most agricultural soils because of its low availability and its poor recovery from the applied fertilizers. The low availability of phosphorus is due to the fact that it readily forms insoluble complexes with cation such as aluminum and iron under acidic soil condition and with calcium and magnesium under alkaline soil conditions whereas the poor $\mathrm{P}$ fertilizer recovery is due to the fact that the P applied in the form of fertilizers is mainly adsorbed by the soil, and is not available for plants lacking specific adaptations. Moreover, global $\mathrm{P}$ reserves are being depleted at a higher rate and according to some estimates there will be no soil P reserve by the year 2050 (Vance et al., 2003; Cordell et al., 2011).

More than $40 \%$ of the world soils are deficient in phosphorus and the acid-weathered soils of tropical and subtropical regions of the world are particularly prone to P deficiency (Vance et al., 2003). On the other hand, in order to cope with the ever increasing world population agricultural production and productivity need to paralelly increase with the increasing population. One option to enhance soil $\mathrm{P}$ availability and hence crop yield is to apply $\mathrm{P}$ containing fertilizers. However, there is scarcity, particularly of chemical fertilizers, in tropical and subtropical regions where most of the earth's population is concentrated. Moreover, lack of fertilizer infrastructures, financial constraints by farmers, and poor transportation facility in the rural areas all make $\mathrm{P}$ fertilization unattainable for these areas. Sustainable management of $\mathrm{P}$ in agriculture requires that professionals in the area of crop sciences discover mechanisms that either enhance plant $\mathrm{P}$ acquisition ability and/or efficient $\mathrm{P}$ utilization ability and further exploit these adaptations to make plants more efficient to thrive under P limiting conditions.

\section{Soil phosphorus status and its availability}

Despite its importance for normal plant growth and metabolism, $\mathrm{P}$ is one of the least accessible nutrients. Many soils are inherently poor in available phosphorus content (Barber, 1995) although the total amount of $\mathrm{P}$ in soil may still be high (Vance et al., 2003). This is evident from the extremely low soil solution $\mathrm{P}$ concentration $(<1 \mu \mathrm{M})$ in sandy soils, alkaline soils and highly weathered soils of tropics and subtropics. Moreover, a large fraction of total soil $\mathrm{P}$ is in organic form in many soils and these forms are not directly available to plants (Smith, 2001; Vance et al., 2003). Many of the agricultural soils in the developing countries in particular are P-deficient (Velk and Koch, 1992) and have an unfavourable condition for P availability (Soltan et al., 1993). It is estimated that crop productivity is limited by $\mathrm{P}$ deficiency on more than $40 \%$ of the world arable lands (Vance, 2001). Additionally, world's resources of $\mathrm{P}$ are limited (Vance et al., 2003).

Unlike nitrate, which readily moves in soil towards the roots via both mass flow and diffusion, phosphate ion is highly immobile in mineral soils. Thus, mass flow delivers only little phosphate ions (1-5\% of plant demand) and the greater portion of 
required phosphate ions reach the root surface via diffusion (Lambers et al., 2006). However, the diffusion coefficient for phosphate ion in soil is very low compared to those for other nutrients (Clarkson, 1981); consequently, plants do not deplete the total volume of the rooted soil layer but only that part of the soil which is in the immediate vicinity of the roots (Föhse and Jungk, 1983).

Phosphorus is commonly bound to iron and aluminium oxides and hydroxides through chemical precipitation or physical adsorption (Kochian et al., 2004). As a result of adsorption, precipitation and conversion to organic forms, only $10-30 \%$ of the applied phosphate mineral fertilizer can be recovered by the crop grown after the fertilization (Holford, 1997; Syers et al., 2008). The rest stays in the soil and may be used by crops in the following years. Because of low P solubility and desorption, only a small proportion of phosphate ions exist in the soil solution for plant uptake even under optimum $P$ fertilization making P fertilizer recovery to be lower compared to other nutrient containing fertilizers (Holford, 1997). This suggests that chemical fertilizer application alone is not a cost effective way of increasing crop production in many P-limiting soils (Tilman et al., 2002). Therefore, the use of genotypes/cultivars with improved root traits able to unlock and absorb $\mathrm{P}$ from bound $\mathrm{P}$ resources and/or effectively utilizing the absorbed $\mathrm{P}$ is of paramount importance for enhancing the efficiency of $\mathrm{P}$ fertilization.

\section{Soil phosphorus management options for sustainable crop production}

Sustainable crop production aims at maintaining high crop yield without adversely affecting ecosystems to meet the need of current as well as future generations (Tilman et al., 2002). Since phosphorus in agriculture is the second most growth limiting macronutrient af- ter nitrogen, its proper management in soil contributes significantly to sustainable crop production. In such soils where yield is limited because of inherent low $\mathrm{P}$ concentration (P deficient soils), application of relatively higher amount of mineral $P$ fertilizers is the only way to enhance soil available P status to a target value in a long run that can sustain high crop yield. However, once the target value is reached, the available soil phosphorus concentration can be kept at a level that can sustain high crop yield through maintenance fertilization (replacing only the P removed from the field along with the harvested crops).

The $\mathrm{P}$ contained in crop residues left in the field can be recycled by incorporating the residues into the soil whereas part of $\mathrm{P}$ in crop residues fed to livestock can be returned back to the soil in the form of manure and also as bone meal. The mineralization of such organic P sources can occur through the action of microorganisms and plants exuding phosphatases and phytases. However, the $\mathrm{P}$ removed along with cereal grains, other edible vegetable parts and livestock products such as cow dung, milk and meat used for human consumption need to be replaced through mineral P fertilizer application. Therefore, under condition where $\mathrm{P}$ removed from the soil by harvested crop can be returned as crop residues and manures, the amount of mineral $P$ fertilizer required for maintenance fertilization becomes less. In a nutshell, regular application of maintenance $P$ fertilizers, incorporation of crop residues and application of organic manures can reduce nutrient mining and contribute to sustainable crop production.

\section{Problems of mineral $p$ fertilization and suggested management options}

The major portion (80-90\%) of mineral $\mathrm{P}$ fertilizers applied to the soil can not be absorbed by plants due to adsorption to $\mathrm{Fe}$ oxides/hydroxides, Al hydroxides 
as well as to $\mathrm{Ca}$ and $\mathrm{Mg}$ carbonate surfaces and due to chemical precipitation. This results in the formation of sparingly soluble Fe-phosphates (strengite) and Al-phosphates (variscite) in acid and Ca-phosphates in alkaline soils. Moreover, the applied mineral P fertilizer may also possibly be transformed to organic form, a process known as microbial immobilization (Holford, 1997). Thus, the mineral P fertilizer recovery of crops during the year of application is usually very low (less than $20 \%$ ).

Mineral P fertilizer recovery of crops can be improved through proper method of $\mathrm{P}$ fertilizers application. In soils that have a high $\mathrm{P}$ fixing capacity, band application (where $\mathrm{P}$ is concentrated in a narrow zone) enhances $\mathrm{P}$ fertilizer recovery compared to broadcasting, since concentrating $\mathrm{P}$ in a small soil volume saturates the $\mathrm{P}$ binding sites and lowers the buffering capacity of the soil thereby increasing mobility of phosphate ion into the soil solution and its further diffusion toward the root. Band application especially of mono-and di-ammonium phosphate fertilizers enhance root proliferation due to both $\mathrm{N}$ and $\mathrm{P}$ effect, consequently improving the P uptake capacity of plants. Similarly, in alkaline soils having a high capacity to precipitate $\mathrm{P}$ as calcium phosphate, addition of organic materials such as farmyard manure along with mineral $\mathrm{P}$ fertilizers improve $\mathrm{P}$ solubilization through microbial activities such as excretion of organic anions, and $\mathrm{H}_{2} \mathrm{CO}_{3}$ formed due to respiration as well as $\mathrm{H}^{+}$released by plant root induced by $\mathrm{NH}_{4}^{+}$ uptake, all of which result in acidification of the rhizosphere. Besides rhizosphere acidification, the organic anions as well as the $\mathrm{H}_{2} \mathrm{CO}_{3}$ may also play role in desorption of phosphate ions adsorbed to $\mathrm{Ca}$ and $\mathrm{Mg}$ carbonates, through ligand exchange reactions. This enhances $\mathrm{P}$ availability contributing to improved mineral $\mathrm{P}$ fertilizer recovery by crops.

\section{P-efficient crops/cultivars and their role in sustainable crop production}

Phosphorus efficiency, which is the ability of a crops/ cultivar to produce high yield under P limiting condition (Graham, 1984), can be attained through improved $\mathrm{P}$ uptake efficiency (the ability to take more $\mathrm{P}$ from the soil under $\mathrm{P}$ limiting condition) and/or through improved P utilization efficiency (the ability to produce higher dry matter yield per unit of $\mathrm{P}$ taken up) (Gahoonia and Nielsen, 1996). Thus, P-efficient cultivars produce reasonably high yield in low $\mathrm{P}$ soils through either ways and thus can reduce mineral $\mathrm{P}$ fertilizer input requirement in agricultural production.

Phosphorus uptake efficient cultivars may contribute to sustainable crop production by producing reasonably high yield under $\mathrm{P}$ deficient condition due to their ability to exploit greater soil volume for accessing more $\mathrm{P}$ through producing larger root system (higher root-shoot ratio), longer root hairs or via forming association with mycorrhiza. Such cultivars may also enhance the applied mineral $P$ fertilizers recovery and improve $\mathrm{P}$ availability, since they may be adapted to mobilize mineral $\mathrm{P}$ fertilizers fixed by the soil after application through exuding organic anions and protons. Additionally, P uptake efficient cultivars may also be able to mineralize organic $\mathrm{P}$ sources (including those of plant and microbial origin) by releasing acid phosphatases, phytases and/or RNase, thereby increasing soil available $\mathrm{P}$ to sustain high yield. Thus, $\mathrm{P}$ uptake efficient cultivars are able to produce high yield at relatively low soil P status which can be reached by applying less amount of mineral $\mathrm{P}$ fertilizer.

On the other hand, P utilization efficient cultivars produce high yield per unit of absorbed $\mathrm{P}$ under $\mathrm{P}$ deficient conditions, since they have low internal $\mathrm{P}$ demand for normal metabolic activities and growth 
and hence have low requirement for mineral $\mathrm{P}$ fertilizer inputs to produce reasonably high yield. Moreover, they remove less $\mathrm{P}$ from soil during growth and therefore the quantity of $\mathrm{P}$ removed along with the harvestable parts of the crop would obviously be less, consequently reducing the quantity of mineral $P$ fertilizer inputs required for maintenance fertilization.

\section{Mechanism of Phosphorus efficiency in plants}

Phosphorus efficiency is a term that generally describes the ability of crop species/genotypes of a given plant species to give higher yield under P-limiting condition (Graham, 1984). Plant species as well as genotypes within the same species may differ in P efficiency (Föhse et al., 1988; Gunes et al., 2006). The ability of a crop/genotype to give higher yield under P-limiting condition may be related to: the ability to take up more P from the soil under P-limiting condition (uptake efficiency) or the ability to produce higher dry matter per unit of $\mathrm{P}$ in the plant tissue (utilization efficiency) or a combination of both (Gahoonia and Nielsen, 1996).

\subsection{P uptake efficiency}

For increased P uptake efficiency, plant species/genotypes may use various adaptation mechanisms to gain access to previously unavailable soil $\mathrm{P}$ reserves such as through altered root morphology, exudation of chemical compounds into the rhizosphere and association of roots with mycorrhiza (Raghothama, 1999; Vance et al., 2003; Lambers et al., 2006) which are discussed throughout 5.1.1 to 5.1.4 of the next section. Higher P uptake efficiency is usually related to either larger root system size (usually higher rootshoot ratio) or to higher uptake rate per unit of root length (Föhse et al., 1988).

\subsubsection{Root morphology}

\section{Root architecture}

Root architecture refers to the complexity of root system spatial configurations that arise in response to soil conditions (Vance et al., 2003). Some plant species/ genotypes alter the architecture of their root systems under $\mathrm{P}$ stress conditions to optimize $\mathrm{P}$ acquisition (Richardson et al., 2011). Adaptations that enhance acquisition of $\mathrm{P}$ from the topsoil are important because of the relative immobility of $\mathrm{P}$ in the soil, with the highest concentrations usually found in the topsoil and little movement of $\mathrm{P}$ into the lower soil profiles (Vance et al., 2003). Studies with Phaseolus indicated that genotypes that have highly branched root systems and more root apices are efficient in acquiring P. Additionally, P-efficient genotypes also grow lateral roots from the basal roots at an angle that enables them to better explore the upper layers of the soil relatively rich in P (Lynch and Brown, 2001). Efficient genotypes develop an architecture that places active roots in regions of the soil more likely to contain available P (Smith, 2001).

\section{Root-shoot ratio}

Because of low mobility of phosphorus in the soil, some plant species/genotypes develop larger root systems that allow a plant to have access to greater soil volume so that higher quantity of soil $\mathrm{P}$ can reach the root surface for uptake (Jungk, 2001). Higher root-shoot ratio is often reported for $\mathrm{P}$ stressed plants as compared with P sufficient plants (Gaume et al., 2001). This is due to severely reduced leaf growth under P stress, which leads to diminished leaf demand for assimilates consequently causing translocation of photosynthates to the root (Cakmak , 1994) for better root growth. Preferential root growth thus helps the 
stressed plants to acquire more $\mathrm{P}$ from the ambient environment in response to $\mathrm{P}$ stress conditions. Difference in P uptake efficiency between crop species (Föhse et al., 1988) and genotypes (Schenk, 2006) was noticed, which was accounted to difference in root-shoot ratio.

\section{Root hairs}

Root surface area alone may not be adequate to feed plants, especially with nutrient of low mobility like phosphorus. The presence of root hairs are therefore, quite important for the acquisition of poorly mobile nutrients such as P (Jungk, 2001). Root hairs are tubular outgrowths on the root surface and their formation is mediated by ethylene production (Michael, 2001). Root hairs substantially increase the root surface area for ion uptake (Gahoonia and Nielsen, 1998; Jungk, 2001). Root hairs have a smaller diameter than roots and grow perpendicular to the root axis, which allows better exploration of soil due to enhanced absorptive surface area (Föhse et al., 1991; Raghothama, 1999). Root hairs form as much as $77 \%$ of the root surface area of field crops (Parker et al., 2000). Root hairs are also effective in extending the width of the $\mathrm{P}$ depletion zone around the root by increasing the volume of the soil explored for phosphorus (Föhse et al., 1991; Smith, 2002).

Some plant species/genotypes are adapted to produce longer and more root hairs under $\mathrm{P}$ deficient conditions (Gahoonia et al., 1999; Bates and Lynch, 2001; Eticha and Schenk, 2001). However, due to overlapping of nutrient depletion zones developing around the root hairs it is not the density but rather the root hair length which is generally considered to be the most important attribute (Sattelmacher et al., 1994). Gahoonia and Nielsen (2004a) demonstrated that a barley genotype with a capacity to form longer root hairs (about $1 \mathrm{~mm}$ ) took up more $\mathrm{P}$, and tended to yield better when $\mathrm{P}$ was limiting crop growth compared to genotypes having root hairs half the length (0.5 mm). Gahoonia and Nielsen (1998) reported that root hairs contribute up to $63 \%$ of the total P uptake under $\mathrm{P}$ deficient condition. Thus, plant species or genotypes of the same species with different root hair length may exhibit different $\mathrm{P}$ uptake efficiency (Eticha and Schenk, 2001). However, unlike in soil culture, root hairs play no significant role in $\mathrm{P}$ acquisition under hydroponic culture, since nutrient diffusion is not a problem under such conditions (Bates and Lynch, 2000). Root hair growth is genetically controlled and thus traits conferring increased root hair length can be utilized in plant breeding programmes (Föhse et al., 1991; Jungk, 2001).

\section{Root radius}

Under P deficient condition, plant species/genotypes produce fine roots that allow a contact of larger soil volume per unit of root surface area, thereby increasing P uptake rates (Föhse et al., 1991; Gahoonia and Nielsen, 2004b). Thus, plant species/genotypes with thinner roots may be more effective in absorbing soil phosphorus (Gahoonia and Nielsen, 2004b). However, since fine roots tend to turnover more rapidly than coarse roots, the carbon cost of producing finer roots may be higher as these will have to be replaced more frequently (Sattelmacher et al., 1994; Gahoonia and Nielsen, 2004b). As a result of this, less consideration is given to select genotypes based on this root morphological trait and to use this trait in breeding programme.

\subsubsection{Cluster root formation}

Proteoid and dauciform root clusters commonly occurring in plant species belonging to Proteaceae, Retinoaceae, Cyperaceae, Fabaceae and few other families are induced by $\mathrm{P}$ deficiency and they are adaptive 
mechanism to maximize $\mathrm{P}$ acquisition from unavailable P resources (Shane and Lambers, 2005; Lambers et al., 2006). Both proteoid and dauciform roots are covered with dense mat of root hairs, which markedly increase the surface area of the root system and are also specialized in efficient synthesis and secretion of organic anions (especially citrate and malate) and phosphatases, which help to solubilize insoluble $\mathrm{P}$ resources and hydrolyze organic $\mathrm{P}$ for plant uptake (Playsted et al., 2006; Lambers et al., 2006). Cluster roots grown under $\mathrm{P}$ deficiency exude 20-to 40-times more citrate and malate than those grown under sufficient P (Vance et al., 2003).

\subsubsection{Association of roots with Arbuscular Mycorrhizae}

The vast majority ( $82 \%$ ) of higher plant species have the capacity to form a symbiotic association with mycorrhizal fungi (Brundrett, 2002). The degree of dependency on mycorrhizal association under P stress could differ with crop species those lacking root hairs such as onion being more dependent on the association (Deressa and Schenk, 2008) and also with cultivars (Zhu et al., 2001). The symbiotic association of plant roots with arbuscular mycorrhiza (AM) enhances the uptake of nutrients with low mobility like $\mathrm{P}$ especially when the species has a root system that is relatively coarse with few root hairs (Graham and Eissenstat, 1994; Sattelmacher et al., 1994). A significant contribution of AM fungi to plant $P$ uptake has been reported especially for soils with low P content and with high P fixing capacity (Marschner and Dell, 1994).

Increased $\mathrm{P}$ absorption by mycorrhizal hyphae is related to both increased physical exploration of the soil and modification of the root environment (Bolan, 1991; Smith and Read, 1997; Tinker and Nye, 2000). Enhanced nutrient absorption through physical exploration of the soil due to mycorrhiza is related to large length of hyphae per unit root length, smaller hyphae radius and larger surface area (Tinker et al., 1992). Particularly the ability of hyphae to extend several centimeters out into the surrounding soil allows to expand the effective volume of the soil that the plant can exploit (Smith, 2002). Arbuscular mycorrhiza fungi also hydrolyze organic phosphate through releasing acid phosphatase into the soil thereby contributing to increased P uptake of the host plant (Tawaraya et al., 2005). Arbuscular mycorrhiza hyphae store polyphosphates in their vacuoles, which may be hydrolyzed in the arbuscules and transported as inorganic $\mathrm{P}$ into the host plant across the plasma membrane of cells (Smith and Gianninazi-Pearson, 1988). The contribution of AM fungi to $\mathrm{P}$ uptake reach up to $77 \%$ under low $\mathrm{P}$ supply compared to only $49 \%$ under high P supply (Thingstrup et al., 2000). Furthermore, Deressa and Schenk (2008) reported that fungal hyphae accounted for nearly the whole of predicted $\mathrm{P}$ uptake by onion.

\subsubsection{Root exudation}

\section{Organic acids}

Plants growing in an ecosystem low in available $\mathrm{P}$ have to obtain $\mathrm{P}$ from adsorbed $\mathrm{P}$, sparingly soluble $\mathrm{P}$ and organic P complexes. Many plants have developed elegant biochemical mechanisms to solubilize $\mathrm{P}$ from insoluble $\mathrm{P}$ complexes thereby increasing the pool of $\mathrm{P}$ available for uptake (Raghothama and Karthikeyan, 2005). Organic anions such as citrate and malate are the major root exudates released, in response to $\mathrm{P}$ deficiency for mobilizing $\mathrm{P}$ for plant uptake (Neumann and Römheld, 1999; Dechassa and Schenk, 2004). The range of organic anions released is, however, dependent on the plant species (Ohwaki and Hirata, 1992; Dechassa and Schenk, 2004). Genotypes of the same species may also differ in their ability to exude organic anions and hence in their ability 
to mobilize P from sparingly soluble P sources (Dong et al., 2004; Corrales et al., 2007). Organic anions mobilize inorganic $\mathrm{P}$ through complexing metal cations that bind phosphate and displace phosphate from the soil matrix by ligand exchange (Raghothama and Karthikeyan, 2005). Besides its role in P solubilization, organic anions exudation also protect the roots of some plants from Al toxicity (Ma et al., 2000) thereby enabling root proliferation and increased foraging capacity for $\mathrm{P}$ in acid soils (Smith, 2001).

\section{Acid phosphatase and phytase}

A major portion (30-80\%) of total $\mathrm{P}$ in soil is present in organic forms (Vance et al., 2003). Half of this is in the form of phytin and its derivatives (Tarafdar and Claassen, 1988). This organic-P complex needs to be hydrolysed by enzymatic activities before the inorganic $\mathrm{P}$ is released into the rhizosphere for plant uptake. Acid phosphatase and phytase are a group of enzymes produced by plants in response to $\mathrm{P}$ stress that can hydrolyse a range of organic-P forms thereby enhancing plant P uptake (Tarafdar and Claassen, 1988; Tarafdar and Claassen, 2001; Richardson et al., 2011) from unavailable $P$ resources. Acid phosphatases functions both as intracellular (vacuolar) and extracellular (secreted) P salvage systems that catalyze the hydrolysis of $\mathrm{P}$ from phosphate-monoesters. The intracellular acid phosphatases play significant role in remobilizing $\mathrm{P}$ during senescence and $\mathrm{P}$ stress (Plaxton, 2004). Phytases secreted by plant roots into the soil hydrolyze the inositol-phosphate while the intracellular phytase will degrade phytic acid which is the principal storage form of phosphorus in seeds and pollen for remobilization and use during seedling growth and pollen germination (Li et al., 1997).

The amount of phytases and acid phosphatases secreted in response to $\mathrm{P}$ deficiency differ between plant species as observed by Li et al. (1997). Increased exu- dation of acid phosphatases was observed in several maize genotypes, except with one genotype under $\mathrm{P}$ deficiency. This indicates that genotypes may also differ in acid phosphatase activity under P stress (Gaume et al., 2001). Similarly, barley genotypes exhibited different extracellular phytase activity under P deficiency (Asmar, 1997). Moreover, secretion of RNase degrades the nucleic acids present in decaying organic matter (Plaxton, 2004). Thus, RNase represents an important source of extracellular $\mathrm{P}$ that is exploited by $\mathrm{P}$ stressed plants. Some plant species/genotypes also release protons into the soil to acidify the rhizosphere condition to enhance P uptake from acid-soluble Caphosphate (Neumann and Römheld, 1999).

\section{Others}

Induction of high-affinity Pi transporters in roots of $\mathrm{P}$ deficient plants also play a crucial role in the acquisition of limited P by some plants (Neumann and Römheld, 1999; Plaxton, 2004). Enhanced expression of high-affinity, plasma membrane-bound Pi transporters in roots and a concomitantly increased P-uptake capacity, was reported as a typical P-starvation response (Dong et al., 1999). However, other reports indicated that diffusion of $\mathrm{P}$ in the soil is the key limiting factor for $\mathrm{P}$ uptake and a change in uptake systems have little effect on the plants capacity to acquire $\mathrm{P}$ from the soil (Raghothama and Karthikeyan, 2005).

\subsection{P utilization efficiency}

Besides increased acquisition of soil $\mathrm{P}$, efficient utilization of acquired $\mathrm{P}$ is also considered an important adaptation for plant growth on low P soils. Phosphorus utilization efficiency refers to the ability of a plant species/genotype to produce higher dry matter per unit of $\mathrm{P}$ absorbed (Blair, 1993; Richardson et al., 2011). 
The mechanism of higher internal $\mathrm{P}$ utilization efficiency is not clearly known. However, it may be related to the ability of a plant in releasing inorganic $\mathrm{P}$ from the storage pool (vacuole) to the cytoplasm (cytoplasmic P homeostasis) (Plaxton and Carswell, 1999; Raghothama, 1999) or to selective allocation of $\mathrm{P}$ between cytoplasm and vacuole in favour of cytoplasm thereby ensuring sufficient Pi concentration in metabolically active compartments for normal functioning of plant metabolism (Lauer et al., 1989a; Raghothama, 1999). Additionally, higher internal $\mathrm{P}$ utilization efficiency may also be due to lower metabolic requirement for inorganic $\mathrm{P}$ at cellular level under P stress possibly due to the presence of alternative P-independent enzymes/metabolic pathways and/or energy sources (Duff et al., 1989; Plaxton and Carswell, 1999).

\subsubsection{Cytoplasmic P homeostasis}

The fastest and largest manifestation of $\mathrm{P}$ starvation is a decline in intracellular $\mathrm{P}(\mathrm{Pi})$ concentration (Natr, 1992). However, plants are still able to maintain cytoplasmic Pi either through effective buffering with vacuolar Pi (Plaxton and Carswell, 1999; Raghothama, 1999) or possibly through selective allocation of Pi between cytoplasm and vacuole to constantly keep sufficient Pi in metablically active compartment (cytoplasm) despite the $\mathrm{P}$ stress as confirmed by ${ }^{31} \mathrm{P}$ nuclear magnetic resonance (NMR) studies (Lauer et al., 1989a). During nutritional P limitation, vacuolar $\mathrm{Pi}$ is released into the cytoplasm in a regulated manner that correlates with the severity of the Pi stress, ultimately ensuring a relatively constant $\mathrm{Pi}$ concentration in the cytoplasm (Mimura et al., 1996). The efficiency of this process is, however, dependent on the relative permeability of the tonoplast to $\mathrm{Pi}$ (Schachtman et al., 1998) and may vary between different plant species. Thus, the decline in cytoplasmic $\mathrm{Pi}$, due to absence of effective Pi homeostasis directly affects sugarphosphate export from the chloroplast (Flügge et al., 1980). This situation leads to the decline in Pi levels in the chloroplast stroma and an increase in starch synthesis (Heldt et al., 1977; Plaxton and Carswell, 1999 ). The decline in the stromal Pi can limit the photosynthetic capacity and hence plant growth rate.

There are divergent reports as to how P deficiency results in non-stomatal induced decline of plant photosynthetic capacity. Most common reports state that $\mathrm{P}$ deficiency reduces photosynthetic capacity through: (i) directly affceting ATP production (Rao et al., 1989), (ii). inactivation of enzymes involved in the ribulose bisphosphate $(\mathrm{RuBP})$ regeneration (Fredeen et al., 1990) (iii) inactivating RuBP carboxylase enzyme which catalyzes $\mathrm{CO}_{2}$ fixation (Lauer et al., 1989b), (iv) combined effect of ii and iii (Brooks et $a l ., 1988$ ). High $\mathrm{P}$ utilization efficiency (high yield or relative growth rate per unit of $\mathrm{P}$ ) of a plant species/ genotypes under $\mathrm{P}$ deficiency can be related to higher net carbon fixation (Yong-fu et al., 2006) achieved possibly through effective cytoplasmic $\mathrm{P}$ homeostasis or through selectively allocating more Pi to the cytoplasm. Higher P utilization efficiency under P limiting condition may also be caused due to lower carbon demand for root respiration (Nielsen et al., 2001).

\subsubsection{The use of P-independent enzymes/pathways in metabolism}

In general, little is known about metabolic adaptations of plant respiratory pathways to $\mathrm{P}$ deficiency. Alternative use of P-independent enzymes instead of P-dependent ones in glycolysis pathways have been reported as plant respiratory adaptation to $\mathrm{P}$ deficiency (Duff et al., 1989; Theodorou and Plaxton, 1996; Plaxton and Carswell, 1999; Plaxton, 2004). Moreover, the P-independent glycolytic enzymes may also facilitate interacellular Pi recycling, since Pi 
is the bi-product of the reactions catalyzed by these enzymes, which can be reassimilated into the metabolism of P stressed plants (Plaxton, 2004). Besides the use of alternative P-independent enzymes, the use of alternative energy source such as the use of pyrophosphate (PPi) in stead of ATP have also been noticed in glycolytic pathways under P stress (Duff et al., 1989; Plaxton and Carswell, 1999). Pyrophosphate is a by-product of anabolic reactions including DNA, RNA, proteins, lipids and polysaccharide biosynthesis (Plaxton and Carswell, 1999). Plant cytosolic PPi levels are remarkebly insensitive to abiotic stresses such as P-starvation, which elicit significant reductions in cellular ATP pools. The large amount of PPi produced during biosynthesis may be employed by plants to enhance the energy efficiency of several cytosolic processes (Plaxton, 2004). Active transport of protons into the vacuole by PPi-dependent $\mathrm{H}^{+}$ pump in the tonoplast can use PPi instead of ATP as an energy donor, which can replaces the limited ATP pool under P deficiency (Duff et al., 1989; Theodorou et al., 1992; Theodorou and Plaxton, 1996; Plaxton and Carswell, 1999). Plants may also use alternative mitochondrial respiration such as nonphosphorylative pathways that can bypass energy-requiring sites (Theodorou and Plaxton, 1993; Vance et al., 2003). This allows continued functioning of the citric acid cycle and respiratory electron transport chain under limited ATP production due to $\mathrm{P}$ stress.

\subsubsection{Maintenance of cell-division and epidermal cell expansion}

One of the most striking effect of P deficiency is a reduction in leaf growth both in terms of leaf number and individual leaf size (Lynch et al., 1991; Chiera et al., 2002). Leaf initiation at the shoot meristem and its lateral expansion are controlled by the activities of cell division (Chiera et al., 2002; Assuero et al., 2004). Pi was reported to play a significant role in cell division activities (Sano et al., 1999). However, plants may still differ in tolerance of $\mathrm{P}$ stress effect on leave growth mainly due to difference in the ability to maintain cell division (Chiera et al., 2002; Assuero et al., 2004), leaf epidermal cell expansion (Radin and Eidenbock, 1984) or both (Kavanova et al., 2006), under lower tissue P concentration. Alternatively, plants may also retranslocate limited $\mathrm{P}$ from older leaves to younger leaves to maintain $\mathrm{Pi}$ at levels that permit optimal physiological activities including cell division (Plaxton and Carswell, 1999; Akhtar et al., 2008).

Other possible mechanism of efficient $\mathrm{P}$ utilization includes conservation of Pi by replacing membrane phospholipids with non-phosphorus galacto and sulfonyl lipids (Plaxton, 2004).

\section{Conclusions}

Global P reserves are rapidely being depleted. Moreover agrciultural soils especially of tropical and subtropical regions of the world are inherently poor in available $\mathrm{P}$ content thus ultimately affecting crop yield. This problem is further aggravated in the aforementioned regions by the absence or sub-optimal application of $P$ fertilizers due lack of financial resources and lack of access to P fertilizers by the farmers making the available soil $\mathrm{P}$ content in these regions to be far below the optimum amount that can sustain higher crop yield. Therefore, maintenance of soil $\mathrm{P}$ at a target value through either of the following ways: application of $\mathrm{P}$ fertilizers, periodic incorporation of crop residue, application of organic manures would be very essential for sustainably higher crop yield. Under conditions where all these soil P management options might not be possible, the use of P-efficient crops or crop genotypes, having desirable traits that enables 
them to have better performance under P stress conditions, might serve as an alternate option for sustainable crop production.

\section{References}

Akhtar, M.S., Oki, Y., Adachi, T. 2008. Genetic variability in phosphorus acquisition and utilization efficiency from sparingly soluble P-sources by Brassica cultivars under P-stress environment. Journal of Agronomy and Crop Science. 194(5),380-392.

Asmar, F. 1997. Variation in activity of root extracellular phytase between genotypes of barley. Plant and Soil 195,61-64.

Asmar. F., Gahoonia, T.S., Nielsen, N.E. 1995. Barley genotypes differ in activities of soluble extracellular phosphatase and depletion of organic phosphorus in the rhizosphere soil. Plant and Soil 182, 117-122.

Assuero, S.G., Mollier, A., Pellerin, S. 2004. The decrease in growth of phosphorus-deficient maize leaves is related to a lower cell production. Plant, Cell and Environment 27,887-895.

Barber, S.A. 1995. Soil Nutrient Bioavailability. a mechanistic approach. $2^{\text {nd }}$ ed. John Wiley and Sons Inc., New York

Bates, T.R., Lynch, J.P. 2000. The efficiency of Arabidopsis thaliana (Brassicaceae) root hairs in phosphate acquisition. American Journal of Botany 87, 964-970.

Bates, T.R., Lynch, J.P. 2001. Root hairs confer a competitive advantage under low phosphorus availability. Plant and Soil 236,243-250.

Blair, G.1993. Nutrient efficiency-what do we really mean? In Randall PJ, Delhaize E, Richards RA, Munns R (eds.) Genetic aspects of plant nutrition. Kluwer Academic Publishers, the Netherlands, pp 204-213.
Bolan, N.S. 1991. A critical review on the role of mycorrhizal fungi in the uptake of phosphorus by plants. Plant and Soil 134,189-207.

Brooks, A., Woo, K.C., Wong, S.C. 1988. Effect of phosphorus nutrition on the response of photosynthesis to $\mathrm{CO}_{2}$ and $\mathrm{O}_{2}$, activation of ribulose bisphosphate carboxylase and amount of ribulose bisphosphate and 3-phosphoglycerate in spinach leaves. Photosynthesis Research 15,133-141.

Brundrett, M.C. 2002. Coevolution of roots and mycorrhizas of land plants. New Phytologist 154, 275-304

Cakmak, I., Hengeler,C. Marschner, H. 1994. Partitioning of shoot and root dry matter and carbohydrates in bean plants suffering from phosphorus, potassium and magnesium deficiency. Journal of Experimental Botany 451245-1250.

Chiera, J., Thomas, J., Rufty, T. 2002. Leaf initiation and development in soybean under phosphorus stress. Journal of Experimental Botany 53,473-481.

Clarkson, D.T. 1981. Nutrient interception and transport by root systems. In: Johnson CB (ed.) Physiological processes limiting plant productivity. London, Butterworths, pp 307-314.

Cordell, D., Rosemarin, A., Schröder, J.J., and Smit, A.L. 2011. Towards global phosphorus security: A systems framework for phosphorus recovery and reuse options. Chemosphere 84,747-758.

Corrales, I., Amenos, M., Poschenrieder, C., Barcelo, J. 2007. Phosphorus efficiency and root exudates in two contrasting tropical maize varieties. Journal of Plant Nutrition 30,887-900.

Dechassa, N., Schenk, M.K. 2004. Exudation of organic anions by roots of cabbage carrot and potato as influenced by environmental factors and plant age. Journal of Plant Nutrition and Soil Science167,623-629. 
Deressa, T.G., Schenk, M.K. 2008. Contribution of roots and hyphae to phosphorus uptake of mycorrhizal onion (Allium cepa L.)-A mechanistic modeling approach. Journal of Plant Nutrition and Soil Science 171,810-820.

Dong, B., Ryan, P.R., Rengel, Z., Delhaize, E. 1999. Phosphate uptake in Arabidopsis thaliana: dependence of uptake on the expression of transporter gene and internal phosphate concentrations Plant, Cell Environment 22,455-146.

Dong, D., Peng, X., Yan, X. 2004. Organic acid exudation induced by phosphorus deficiency and/ or aluminium toxicity in two contrasting soybean genotypes. Physiologia Plantarum 122,190-199.

Duff, S.M.G., Moorhead, G.B.G., Lefebvre, D.D., Plaxton, W.C. 1989. Phosphate starvation inducible bypasses of adenylate and phosphate dependent glycolytic enzymes in Brassica nigra suspension cells. Plant Physiology 90,1275-1278.

Eticha, D. 2001. Phosphorus efficiency of cabbage varieties. MSc Thesis, Institute of Plant Nutrition, University of Hannover, Germany

Eticha, D., Schenk, M.K. 2001. Phosphorus efficiency of cabbage varieties. In: Horst et al. (eds.) Plant nutrition-food security and sustainability of agroecosystems through basic and applied research. Kluwer Academic Publisher Dordrecht, the Netherlands, pp 542-543.

Flügge, U.I., Freisl, M., Heldt, H.W. 1980. Balance between metabolite accumulation and transport in relation to photosynthesis by spinach chloroplasts. Plant Physiology 65,574-577.

Föhse, D., Claassen, N., Jungk, A. 1988. Phosphorus efficiency of plants. I. External and internal $\mathrm{P}$ requirement and $\mathrm{P}$ uptake efficiency of different plant species. Plant and Soil 110,101-109.

Föhse, D., Claassen, N., Jungk, A. 1991. Phosphorus efficiency of plants. II. Significance of root radius, root hairs and cation-anion exchange balance for phosphorus influx in seven plant species. Plant and Soil 132,261-272.

Föhse, D., Jungk, A. 1983. Influence of phosphate and nitrate supply on root hair formation of rape, spinach and tomato plants. Plant and Soil 74,359-368.

Fredeen, A.L., Raab, T.K., Rao, M., Terry, N. 1990. Effect of phosphorus nutrition on photosynthesis in Glycine max (L.) Merr. Planta 181,399-405.

Gahoonia, T.S., Nielsen, N.E. 1996. Variation in acquisition of soil phosphorus among wheat and barley genotypes. Plant and Soil 178,223-230.

Gahoonia, T.S., Nielsen, N.E. 1998. Direct evidence on participation of root hairs in phosphorus $\left({ }^{32} \mathrm{P}\right)$ uptake from soil. Plant and Soil 198,147-152.

Gahoonia, T.S., Nielsen, N.E. 2004a. Barley genotypes with long root hairs sustain high grain yields in low-P field. Plant and Soil 262,55-62.

Gahoonia, T.S., Nielsen, N.E. 2004b. Root traits as tools for creating phosphorus efficient crop varieties. Plant and Soil 260,47-57.

Gahoonia, T.S., Nielsen, N.E., Lyshede, O.B. 1999. Phosphorus (P) acquisition of cereal cultivars in the field at three levels of $\mathrm{P}$ fertilization. Plant and Soil 211,269-281.

Gaume, A., Mächler, F., De Leon, C., Narro, L., Frossard, E. 2001. Low-P tolerance by maize (Zea mays L.) genotypes: Significance of root growth, and organic acids and acid phosphatase root exudation. Plant and Soil 228,253-264.

Graham, J.H., Eissenstat, D.M. 1994. Host genotype and the formation of VA mycorrhizae. Plant and Soil 159,179-185.

Graham, R.D. 1984. Breeding for nutritional characteristic in cereals. In: Tinker PB ,Lauchli A (eds.) Advances in Plant Nutrition. Praeger, New York. 1, pp 57-102.

Gunes, A., Inal, A., Aplaslan, M., Cakmak, I. 2006. Genotypic variation in phosphorus efficiency be- 
tween wheat cultivars grown under greenhouse and field conditions. Soil Science and Plant Nutrition $52,470-478$.

Heldt, H.W., Chon, C.J., Maronde, D., Herold, A., Stankovic, Z.S., Walker, D.A., Kraminer, A., Kirk, M.R. and Heber, U. 1977. Role of orthophosphate and other factors in the regulation of starch formation in leaves and isolated chloroplasts. Plant Physiology 59,1146-1155.

Holford, I.C.R. 1997. Soil phosphorus: its measurements and its uptake by plants. Australian Journal of Soil Research 35,227-239.

Jungk, A. 2001. Root hairs and acquisition of plant nutrients from soil. Journal of Plant Nutrition and Soil Science 164,121-129.

Kavanova, M., Lattanzi, F.A., Grimoldi, A.A., Schnyder, H. 2006. Phosphorus deficiency decreases cell division and elongation in grass leaves. Plant Physiology 141,766-775.

Kochian, L.V., Hoekenga, O.A., Pineros, M.A. 2004. How do crop plants tolerate acid soils? Mechanisms of aluminium tolerance and phosphorus efficiency. Annual Review of Plant Biology 55, 459-493.

Lambers, H., Shane, M.W., Cramer, M.D., Pearse, S.J., Veneklaas, E.J. 2006. Root structure and functioning for efficient acquisition of phosphorus: matching morphological and physiological traits. Annals of Botany 98,693-713.

Lauer, M.J., Blevins, D.G., Sierputowska-Gracz, H. 1989a. ${ }^{31} \mathrm{P}$-nuclear magnetic resonance determination of phosphate compartmentation in leaves of reproductive soybeans (Glycine max L.) as affected by phosphate nutrition. Plant Physiology 89,1331-1336.

Lauer, M.J., Pallardy, G.S., Blevins, D.G., Randall, D.D. 1989b. Whole leaf carbon exchange characteristic of phosphate deficient soybeans (Glycine $\max$ L.). Plant Physiology 91,848-854.
Li, M., Osaki, M., Rao, I.M., Tadano, T. 1997. Secretion of phytase from roots of several species under phosphorus deficient conditions. Plant and Soil 195,161-169.

Lynch, J., Läuchli, A., Epstein, E. 1991. Vegetative growth of common bean in response to phosphorus nutrition. Crop Science 31,380-387.

Lynch, J.P., Brown, K.M. 2001. Topsoil foraging-an architectural adaptation of plants to low phosphorus. Plant and Soil 237,225-237.

Ma, J.F. 2000. Role of organic acids in detoxification of aluminium in higher plants. Plant Cell Physiology 41,383-390.

Marschner, H., Dell, B. 1994. Nutrient uptake in mycorrhizal symbiosis. Plant and Soil 159,89-102.

Michael, G. 2001. The control of root hair formation: suggested mechanisms. Journal of Plant Nutrition and Soil Science 164,111-119.

Mimura, T., Sakano, K., Shimmen, T. 1996. Studies on the distribution, re-translocation and homeostasis of inorganic phosphate in barley leaves. Plant, Cell and Environment 19,311-320.

Natr, L. 1992. Mineral nutrients-a ubiquitous stress factor for photosynthesis. Photosynthetica 27, 271-294.

Neumann, G., Römheld, V. 1999. Root excretion of carboxylic acids and protons in phosphorus-deficient plants. Plant and Soil 211,121-130.

Nielsen, K.L., Eshel, A., Lynch, J.P. 2001. The effect of phosphorus availability on the carbon economy of contrasting common bean (Phaseolus vulgaris L.) genotypes. Journal of Experimental Botany 52,329-339.

Ohwaki, Y., Hirata, H. 1992. Differences in carboxylic acid exudation among P-starved leguminous crops in relation to carboxylic acid content in plant tissues and phospholipids levels in roots. Soil Science and Plant Nutrition 38,235-243. 
Parker, J.S., Cavell, A.C., Dolan, L., Roberts, K., Grierson, C.S. 2000. Genetic interactions during root hair morphogenesis in Arabidopsis. Plant Cell 12, 1961-1974.

Plaxton, W.C. 2004. Plant response to stress: Biochemical adaptations to $\mathrm{P}$ deficiency. Encyclopedia of Plant and Crop Science. Marcel Dekker, Inc., pp 976-980.

Plaxton, W.C., Carswell, M.C. 1999. Metabolic aspects of the phosphate starvation response in plants. In: Lerner HR (ed.) Plant response to environmental stress: from phytohormones to genome reorganization. New York, NY, USA: MarcelDekker, pp 350-372.

Playsted, C.W.S., Johnston, M.E., Ramage, C.M., Edwards, D.G., Cawthray, G.R., Lambers, H. 2006. Functional significance of dauciform roots: exudation of carboxylates and acid phosphatase under phosphorus deficiency in Caustis blakei (Cyperaceae). New Phytologist 170,491-500.

Radin, J.W., Eidenbock, M.P. 1984. Hydraulic conductance as a factor limiting leaf expansion of phosphorus-deficient cotton plants. Plant Physiology 75,372-377.

Raghothama, K.G. 1999. Phosphate acquisition. Annual Review of Plant Physiology and Plant Molecular Biology 50,665-693.

Raghothama, K.G., Karthikeyan, A.S. 2005. Phosphate acquisition. Plant and Soil 274, 37-49.

Rao, M., Arulanantham, A.R., Terry, N. 1989. Leaf phosphate status, photosynthesis and carbon partitioning in sugar beet. Plant Physiology 90, 820-826.

Richardson, A. E., Lynch, J.P., Ryan, P.R., Delhaize E., Smith, F. A., Smith, S.E., Harvey P.R., Ryan M.H., Veneklaas E.J., Lambers, H., Oberson, A., Culvenor R.A., Simpson, R.J. 2011. Plant and microbial strategies to improve the phosphorus efficiency of agriculture. Plant and soil 349,121-156.
Sano, T., Kuraya, Y., Amino, S., Toshiyuki, N. 1999. Phosphate as a limiting factor for cell division of tobacco BY-2 Cells. Plant Cell Physiology 40,1-8.

Sattelmacher, B., Horst, W.J., Becker, H.C. 1994. Factors that contribute to genetic variation for nutrient efficiency of crop plants. Z. Pflanzenernähr. Bodenk. 157,215-224.

Schachtman, D.P., Reid, R.J., Ayling, S.M. 1998 Phosphorus uptake by plants: from soil to cell. Plant Physiology 116,447-453.

Schenk, M.K. 2006. Nutrient efficiency of vegetable crops. Acta Hort. (ISHS). 700,21-34.

Shane, M.W., Lambers, H. 2005. Cluster roots: curiosity in context. Plant and Soil 274,99-123.

Smith, F.W. 2001. Plant response to nutritional stresses. In: Hawkesford MJ, Buchner P (eds.) Molecular analysis of plant adaptation to the environment. Kluwer Academic Publishers. The Netherlands. pp 249-269.

Smith, F.W. 2002. The phosphate uptake mechanism Plant and Soil 245,105-114.

Smith, S.E., Gianninazi-Pearson, V. 1988. Physiological interactions between symbiots in vesiculararbuscular mycorrhiza plants. Annual Review of Plant Physiology and Plant Molecular Biology 39, 221-224.

Smith, S.E., Read, D.J. 1997. Mycorrhizal symbiosis. Academic Press, San Diego, California

Soltan, S., Römer, W., Adgo, E., Gerke, J., Schilling, G. 1993. Phosphorus sorption by Egyptian, Ethiopian and German soils and $\mathrm{P}$ uptake by rye (Secale cereale L.) seedlings. Z. Pflanzenenähr. Bodenkd. 156,501-506.

Syers, J.K., Johnston, A.E., Curtin, D. 2008. Efficiency of Soil and Fertilizer Phosphorus: Reconciling Changing Concepts of Soil Phosphorus Behaviour with Agronomic Information. FAO Fertilizer and Plant Nutrition Bulletin 18,108. (FAO: Rome). 
Tarafdar, J.C., Claassen, N. 1988. Organic phosphorus compounds as a phosphorus source for higher plants through the activity of phosphatases produced by plant roots and microorganisms. Biology and Fertility of Soils 5,308-312.

Tarafdar, J.C., Claassen, N. 2001. Comparative efficiency of acid phosphatase originated from plant and fungal sources. Journal of Plant Nutrition and Soil Science 164,279-282.

Tawaraya, K., Ohtaki, M., Tanimura, Y., Wagatsuma, T. 2005. Mineralization of organic phosphate by hyphal exudates of arbuscular mycorrhizal. In: $\mathrm{Li}$ et al. (eds.) Plant nutrition food security, human health and environmental protection. pp 790-791.

Theodorou, M.E., Plaxton, W.C. 1993. Metabolic adaptation of plant respiration to nutritional phosphate deprivation. Plant Physiology 101,339-344.

Theodorou, M.E., Plaxton, W.C. 1996. Purification and characterization of pyrophosphate-dependent phosphofruktokinase from phosphate starved Brassica nigra suspension cells. Plant Physiology 112,343-351.

Thingstrup, I., Kahiluoto, H., Jakobsen, I. 2000. Phosphate transport by hyphae of field communities of arbuscular mycorrhiza fungi at two levels of $\mathrm{P}$ fertilization. Plant and Soil 221,181-187.

Tilman, D., Cassman, K.G., Matson, P.A., Naylor, R., Polasky, S. 2002. Agricultural sustainability and intensive production practices. Nature 418,671-677.
Tinker, P.B., Jones, M.D., Durall, D.M. 1992. A functional comparison of ecto-and endomycorrhizas. In: Read DJ, Lewis DH, Fitter AH, Alexander J (eds.) Mycorrhiza in ecosystems. CAB International, Wellingford, UK, pp 303-310.

Tinker, P.B., Nye, P.H. 2000. Solute movement in the rhizosphere. Oxford University Press, Inc.

Vance, C.P. 2001. Symbiotic nitrogen fixation and phosphorus acquisition: plant nutrition in a world of declining renewable resources. Plant Physiology 127,390-397.

Vance, C.P., Uhde-Stone, C., Allan, D. 2003. Phosphorus acquisition and use: critical adaptation by plants for securing non-renewable resources. New Phytologist 15,423-447.

Vlek, P.L.G., Koch, H. 1992. The soil resource base and food production in the developing world: special focus on Africa. Gättinger Beitrage zur Landund Forstwirschaft in den Tropen und Subtropen 71,139-160.

Yong-fu, L., An-cheng, L., Hassan, M.J., Xing-hua, W. 2006. Effect of phosphorus deficiency on leaf photosynthesis and carbohydrates partitioning in two rice genotypes with contrasting low $\mathrm{P}$ susceptibility. Rice Science 13,283-290.

Zhu, Y.G., Smith, S.E., Barritt, A.R., smith, F.A. 2001. Phosphorus (P) efficiency and mycorrhizal responsiveness of old and modern wheat cultivars. Plant and Soil 237,249-255. 
